\title{
Endocytosis, cell signalling, adhesion and motility
} HT McMahon

\author{
Address: Neurobiology Division, MRC Laboratory of Molecular Biology, Cambridge, UK \\ from 12th Joint Meeting of the Signal Transduction Society (STS). Signal Transduction: Receptors, Mediators and Genes \\ Weimar, Germany. 29-31 October 2008 \\ Published: 26 February 2009 \\ Cell Communication and Signaling 2009, 7(Suppl I):AI0I doi:I0.I I86/I478-8IIX-7-SI-A I0I
}

This abstract is available from: http://www.biosignaling.com/content/7/SI/AI0I

(c) 2009 McMahon; licensee BioMed Central Ltd.

Endocytosis and exocytosis play a key role in how cells respond to their environment. Endocytosis directly (and indirectly) affects responses to guidance cues and growth factors, the uptake of nutrients and even pathogens; it modulates cell signalling in response to receptor activation and is essential for cell migration. In this talk I will consider the endocytic repertoire of a cell and show how distinct mechanisms may differently affect function. I will describe the characterisation of new endocytic mechanisms and show how a molecular understanding can lead to a better view of function. I will round up with a simple view of how exocytosis can be regulated by calcium mediated signalling.

\section{References}

I. Mittal R, Peak-Chew S-Y, McMahon HT: Acetylation of MEK2 and IkB kinase (IKK) activation loop residues by YopJ inhibits signalling. Proc Natl Acad Sci USA 2006, 103:18574-18579.

2. Schmid EM, McMahon HT: Integrating molecular and network biology to decode endocytosis. Nature 2007, 448:883-888.

3. Martens S, McMahon HT: Mechanisms of membrane fusion: disparate players and common principles. Nat Rev Mol Cell Biol 2008, 9:543-556.

4. Daumke O, Lundmark R, Vallis Y, Martens S, Butler J, McMahon HT: Architectural and mechanistic insights into an EHD ATPase involved in membrane remodelling. Nature 2007, 449:923-927. 